Article

\title{
Analyzing the Effectiveness of Textbooks for Vocabulary Retention
}

\author{
Rachael Ruegg and Cherie Brown \\ Akita International University \\ doi: http://dx.doi.org/10.7820/vli.v03.2.ruegg.brown
}

\begin{abstract}
Although many language educators are aware of factors necessary for vocabulary acquisition and retention, in many institutions around the world instructors are required to use textbooks as a basis for instruction, yet, to date, little has been done to analyze the effectiveness of textbooks to foster vocabulary acquisition and retention. Therefore, the purpose of the present study was to analyze the vocabulary content of a range of textbooks. The number of target words, frequency level of those words and length of reading texts were analyzed in reading texts and their associated activities of 20 English as a Second Language (ESL)/English as a Foreign Language (EFL) textbooks. It was found that each text had as little as no target words and on average 10, while the average text length was 639 words. In terms of the frequency level of the target vocabulary, although the textbooks claimed to be at an intermediate level or above, the frequency level of the target vocabulary was very inconsistent, with as many as $60 \%$ of target words coming from the first 1000 words or as many as $100 \%$ of target words being low frequency 'offlist' words. Furthermore, it was found that integrated skills textbooks had significantly fewer target words and significantly shorter reading texts than reading textbooks, while they also had a significantly higher percentage of words from the 1000 word list and a significantly lower percentage from the Academic Word List (AWL).
\end{abstract}

\section{Background}

A great number of studies have examined different factors necessary for vocabulary acquisition and retention, and many language educators are aware of these factors. For example, it is widely accepted that learners should begin their vocabulary acquisition by learning the most common words in the target language, as these provide greater coverage of written text and spoken language than other words. In the study of English vocabulary, in particular, the General Service Lists (West, 1953) of the most frequent 2000 words in the English language are the most commonly referred to for vocabulary instruction and research. After the first 2000 words have been acquired, it is generally agreed that the next focus should be the 570 academic words in the Academic Word List (AWL) for learners who hope to use the language for academic purposes (Coxhead, 2000).

However, in many institutions around the world, instructors are required by their institutions, or education ministries, to use prescribed textbooks as a basis for 
instruction. Indeed, many instructors who are not required to use textbooks also choose to do so. To date, textbooks have not been analyzed in terms of their effectiveness to foster vocabulary acquisition and retention. Therefore, the purpose of the present study was to analyze a range of textbooks which are widely available and commonly used internationally in the instruction of English as a Foreign Language (EFL), English as a Second Language (ESL) and English for Academic Purposes (EAP) with a view to discovering the extent to which they foster vocabulary acquisition and retention opportunities.

The terms 'beginner', 'elementary', 'intermediate' and 'advanced' have often been used to describe the proficiency level of learners, and these terms continue to be used in many contexts. Similarly, these terms are often used to describe the levels of textbooks. However, the terms are subjective and little effort has been made to determine what they might mean in quantifiable terms. Perhaps the closest the field of language education has to a consensus on language proficiency levels is the Common European Framework of Reference for Languages (CEFR; Council of Europe, 2001), which was created in an attempt to more objectively measure learners' language proficiency levels. However, many of the descriptors used in the CEFR are also difficult to quantify and therefore, in practice, the CEFR 'rests on the poles of teacher perceptions' (Hulstijn, 2007). More specifically, in terms of vocabulary knowledge, there is also considerable range in the amount of vocabulary known by learners based on their context of study. For example, EFL learners typically know less vocabulary than their ESL counterparts because of their relative lack of exposure to the target language.

Although the issue of how much vocabulary learners should be expected to know at a given proficiency level is somewhat opaque, textbook producers still need to decide what target vocabulary to focus on in their books. As a rough guide, graded reader series provide an estimate of how much vocabulary learners may know at various proficiency levels. The vocabulary levels of three series of graded readers (Cambridge, Macmillan and National Geographic) were used to determine a rough guide to the level of vocabulary that should be taught to learners at different levels of proficiency. From the data in Table 1, which were compiled from the information offered by the three publishers, it can be seen that beginners to pre-intermediate level learners should be focusing on the first 1000 words, elementary to intermediate level learners should be focusing on the second 1000 words and upper-intermediate to advanced level learners should be focusing on vocabulary beyond the first 2000 words. In terms of the CEFR, learners at the A1 and A2 levels should be focusing on the first 1000 words, from A2 to B2 should be focusing on the second 1000 words and from B2 upwards should be focusing on words beyond the first 2000 words.

Not only do learners need to focus deliberately on vocabulary during study, but they also need to encounter target words repeatedly, in order to remember them. According to Folse (2004), encountering a new word multiple times enables it to be moved from short-term to long-term memory and thus retained. Similarly, Cobb (1999) found that when learners encounter words in a variety of different contexts, they are better able to retain them. Consequently, not only do the target words need to be included as many times as possible in a text, but previously learned words also need to be recycled regularly (Nation, 2001). 
Table 1. Graded-reader Vocabulary Levels

\begin{tabular}{llrl}
\hline Publisher & \multicolumn{1}{c}{ Level } & Words & CEFR \\
\hline Cambridge & Beginner/elementary & 400 & A1 \\
Cambridge & Elementary/lower-intermediate & 800 & A2 \\
Cambridge & Lower-intermediate & 1300 & B1 \\
Cambridge & Intermediate & 1900 & B1 \\
Cambridge & Upper-intermediate & 2800 & B2 \\
Cambridge & Advanced & 3800 & C1 \\
Macmillan & Starter & 300 & \\
Macmillan & Beginner & 600 & A1 \\
Macmillan & Elementary & 1100 & \\
Macmillan & Pre-intermediate & 1400 & A2-B1 \\
Macmillan & Intermediate & 1600 & B1-B2 \\
Macmillan & Upper & 2200 & \\
National Geographic & Pre-intermediate & $800-1000$ & A2 \\
National Geographic & Intermediate & $1300-1600$ & B1 \\
National Geographic & Upper-intermediate & $1900-2200$ & B2 \\
National Geographic & Advanced & $2600-3000$ & C1 \\
\hline
\end{tabular}

\section{Research Method}

This research analyzed the target vocabulary content of 20 textbooks which are widely available and commonly used internationally in the instruction of EFL, ESL and EAP. For the purposes of comparison, 10 reading textbooks and 10 integrated skills textbooks were selected and the fifth reading text of each book was analyzed. The textbooks used in the analyzis are listed in Table 2.

In order to ascertain the target vocabulary, one reading text and all vocabulary activities related to the text (pre-reading, post-reading, review and expansion activities) were examined. A word which appeared in the reading text and at least one activity was considered to be a target vocabulary item. The length of texts was compared, in order to determine the amount of exposure to text that learners gain from the textbook because text exposure gives learners the chance to encounter new words multiple times and also recycles previously learnt words. In the analyzis of the frequency level of the target vocabulary, the lexical profiling tool 'Web Vocabprofile' (Cobb, n.d.; Heatley, Nation, \& Coxhead, 2002) was used. The tool calculates both the number of words at each of four frequency levels (1000 word level, 2000 word level, AWL and offlist) and the text coverage in the form of percentages.

\section{Results}

\subsection{Preliminary Analyzis}

The descriptive statistics for the length of texts (in words) and the number of target words can be seen in Table 3 . 
Table 2. Textbooks analyzed

\begin{tabular}{|c|c|c|c|c|c|}
\hline Title & Author(s) & Publisher & Year & Level & Type \\
\hline Aspire & $\begin{array}{l}\text { Dummett, P., Robb } \\
\text { Benne, R., } \\
\text { Crossley, R. }\end{array}$ & $\begin{array}{l}\text { Heinle } \\
\text { Cengage } \\
\text { Learning }\end{array}$ & 2013 & $\begin{array}{l}\text { Upper- } \\
\text { intermediate } \\
\text { B2 }\end{array}$ & $\begin{array}{l}\text { Integrated } \\
\text { skills }\end{array}$ \\
\hline College Reading & Avery, J., Fellag, L. & $\begin{array}{l}\text { Thomson } \\
\text { Heinle }\end{array}$ & 2006 & Upper & Reading \\
\hline $\begin{array}{l}\text { Concepts and } \\
\text { comments }\end{array}$ & $\begin{array}{l}\text { Ackhert, P. } \\
\text { Lee, L. }\end{array}$ & $\begin{array}{l}\text { Heinle } \\
\text { Cengage } \\
\text { Learning }\end{array}$ & 2005 & $\begin{array}{l}\text { Upper- } \\
\text { intermediate }\end{array}$ & Reading \\
\hline $\begin{array}{l}\text { Focus on } \\
\text { vocabulary } 2\end{array}$ & $\begin{array}{l}\text { Schmitt, D. } \\
\text { Schmitt, N. }\end{array}$ & $\begin{array}{l}\text { Pearson } \\
\text { Longman }\end{array}$ & 2011 & $\begin{array}{l}\text { Upper- } \\
\text { intermediate }\end{array}$ & Reading \\
\hline Global Outlook & $\begin{array}{l}\text { Bushell, B. } \\
\text { Dyer, B. }\end{array}$ & McGraw Hill & 2013 & Intermediate & Reading \\
\hline Just Right & $\begin{array}{l}\text { Harmer, J. } \\
\text { Lethaby, C. }\end{array}$ & $\begin{array}{l}\text { Heinle } \\
\text { Cengage } \\
\text { Learning }\end{array}$ & 2012 & $\begin{array}{l}\text { Upper- } \\
\text { intermediate }\end{array}$ & $\begin{array}{l}\text { Integrated } \\
\text { skills }\end{array}$ \\
\hline Key Concepts 2 & $\begin{array}{l}\text { Smith-Palinkas, B. } \\
\text { Croghan-Ford, K. }\end{array}$ & $\begin{array}{l}\text { Heinle } \\
\text { Cengage } \\
\text { Learning }\end{array}$ & 2010 & Intermediate & Reading \\
\hline Mosaic 1 & $\begin{array}{l}\text { Wegmann, B. } \\
\text { Knezevic, M. }\end{array}$ & McGraw Hill & 2014 & $\begin{array}{l}\text { Intermediate - } \\
\text { high- } \\
\text { intermediate }\end{array}$ & Reading \\
\hline New English File & $\begin{array}{l}\text { Oxenden, C. } \\
\text { Latham-Koenig, C. }\end{array}$ & Oxford & 2008 & $\begin{array}{l}\text { Upper- } \\
\text { intermediate } \\
\text { B2 }\end{array}$ & $\begin{array}{l}\text { Integrated } \\
\text { skills }\end{array}$ \\
\hline New Headway & $\begin{array}{l}\text { Soars, L. } \\
\text { Soars, J. }\end{array}$ & Oxford & 2005 & $\begin{array}{l}\text { Upper- } \\
\text { intermediate } \\
\text { B2 }\end{array}$ & $\begin{array}{l}\text { Integrated } \\
\text { skills }\end{array}$ \\
\hline Outcomes & $\begin{array}{l}\text { Dellar, H. } \\
\text { Walkley, A. }\end{array}$ & $\begin{array}{l}\text { Heinle } \\
\text { Cengage } \\
\text { Learning }\end{array}$ & 2010 & $\begin{array}{l}\text { Upper- } \\
\text { intermediate } \\
\text { B2 }\end{array}$ & $\begin{array}{l}\text { Integrated } \\
\text { skills }\end{array}$ \\
\hline Passages 1 & $\begin{array}{l}\text { Richards, J. } \\
\text { Sandy, C. }\end{array}$ & Cambridge & 2008 & $\begin{array}{l}\text { Upper- } \\
\text { intermediate }\end{array}$ & $\begin{array}{l}\text { Integrated } \\
\text { skills }\end{array}$ \\
\hline $\begin{array}{r}\text { Q: Skills for } \\
\text { Success } 5\end{array}$ & $\begin{array}{l}\text { Caplan, N. } \\
\text { Roy Douglas, S. }\end{array}$ & Oxford & 2011 & & Reading \\
\hline Quest 2 & Hartmann, P. & McGraw Hill & 2007 & $\begin{array}{l}\text { Intermediate-- } \\
\text { high- } \\
\text { intermediate }\end{array}$ & Reading \\
\hline $\begin{array}{l}\text { Reading } \\
\text { Explorer } 4\end{array}$ & Maclntyre, P. & $\begin{array}{l}\text { Heinle } \\
\text { Cengage } \\
\text { Learning }\end{array}$ & 2010 & $\begin{array}{l}\text { Upper- } \\
\text { intermediate } \\
\text { C1 }\end{array}$ & Reading \\
\hline Select Readings & $\begin{array}{l}\text { Lee, L. } \\
\text { Bernard, J. }\end{array}$ & Oxford & 2011 & $\begin{array}{l}\text { Upper- } \\
\text { intermediate } \\
\text { B2 }\end{array}$ & Reading \\
\hline World Class 2 & $\begin{array}{l}\text { Douglas, N. } \\
\text { Morgan, J. }\end{array}$ & $\begin{array}{l}\text { Cengage } \\
\text { Learning }\end{array}$ & 2013 & $\begin{array}{l}\text { Advanced } \\
\text { C1 }\end{array}$ & $\begin{array}{l}\text { Integrated } \\
\text { skills }\end{array}$ \\
\hline World English 3 & $\begin{array}{l}\text { Johannsen, } \mathrm{K} . \\
\text { Tarver Chase, R }\end{array}$ & $\begin{array}{l}\text { Heinle } \\
\text { Cengage } \\
\text { Learning }\end{array}$ & 2010 & $\begin{array}{l}\text { Intermediate } \\
\text { B1 }\end{array}$ & $\begin{array}{l}\text { Integrated } \\
\text { skills }\end{array}$ \\
\hline World Link 3 & $\begin{array}{l}\text { Stempleski, S., } \\
\text { Morgan, J., } \\
\text { Douglas, N. }\end{array}$ & $\begin{array}{l}\text { Heinle } \\
\text { Cengage } \\
\text { Learning }\end{array}$ & 2011 & $\begin{array}{l}\text { Intermediate } \\
\text { B2 }\end{array}$ & $\begin{array}{l}\text { Integrated } \\
\text { skills }\end{array}$ \\
\hline
\end{tabular}


Table 2 (Continued)

\begin{tabular}{llllll}
\hline Title & \multicolumn{1}{c}{ Author(s) } & Publisher & Year & Level & Type \\
\hline World Pass & Stempleski, S., & Thomson & 2006 & $\begin{array}{l}\text { Upper- } \\
\text { intermediate }\end{array}$ & $\begin{array}{l}\text { Integrated } \\
\text { skills }\end{array}$ \\
& $\begin{array}{l}\text { Morgan, J., } \\
\text { Douglas, N., } \\
\text { Johannsen, K. }\end{array}$ & & & & \\
\hline
\end{tabular}

The descriptive statistics for the percentage of target words at each frequency level can be seen in Table 4 .

While analyzing the text length, number and frequency level of target words, there appeared to be clear differences between the integrated skills textbooks and reading textbooks. For this reason, it was decided to conduct an additional analyzis, comparing the text length, number and frequency level of target vocabulary between the two types of textbooks.

Table 3. Descriptive Statistics for Text Length and Target Words

\begin{tabular}{lrrrr}
\hline Variable & Mean & SD & Min & Max \\
\hline Text length & 639 & 313 & 243 & 1221 \\
Target words & 10 & 6 & 0 & 25 \\
\hline
\end{tabular}

Table 4. Descriptive Statistics for Frequency Levels of Target Words

\begin{tabular}{lcccc}
\hline Frequency & Mean (\%) & SD & Min & Max (\%) \\
\hline 1000 words & 17.17 & 19.64 & 0 & 60.00 \\
2000 words & 13.17 & 16.42 & 0 & 66.67 \\
AWL & 30.17 & 31.14 & 0 & 100 \\
Offlist & 34.50 & 27.10 & 0 & 100 \\
\hline
\end{tabular}

\subsection{Additional Analyzis}

Table 5 shows the descriptive statistics for the text length (in words) and the number of target vocabulary items in both types of textbooks.

Independent samples $t$-tests were conducted to determine whether there were any significant differences between the two types of textbooks in terms of text length or number of target words. It was found that there was a significant difference (at the 0.05 level) between reading textbooks and integrated skills textbooks both in terms of the length of texts (in words), $(t=8.86, d f=18, p=$ $.001)$ and the number or target words, $(t=2.57, d f=18, p=.0019)$.

Table 6 shows the descriptive statistics for the frequency level of the target words in both types of textbooks. 
Table 5. Descriptive Statistics for Text Length and Target Words by Text Type

\begin{tabular}{llrrrr}
\hline Variable & Text type & \multicolumn{1}{c}{ Mean } & \multicolumn{1}{c}{ SD } & Min & Max \\
\hline Text length & Reading & 860.90 & 289.89 & 432 & 1221 \\
& Int. skills & 417.00 & 116.10 & 243 & 616 \\
Target words & Reading & 12.90 & 6.59 & 6 & 25 \\
& Int. skills & 6.90 & 3.35 & 0 & 12 \\
\hline
\end{tabular}

Table 6. Descriptive Statistics for Frequency Levels of Target Words by Text Type

\begin{tabular}{llrccc}
\hline Frequency & Text type & Mean & SD & Min & Max \\
\hline \multirow{2}{*}{ 1000 words } & Reading & 7.82 & 10.61 & 0 & 27.27 \\
& Integrated skills & 26.51 & 22.52 & 0 & 60 \\
\multirow{3}{*}{ wWr words } & Reading & 14.65 & 20.80 & 0 & 66.67 \\
& Integrated skills & 11.68 & 11.48 & 0 & 33.33 \\
& Reading & 48.22 & 34.17 & 0 & 100 \\
Offlist & Integrated skills & 12.12 & 12.51 & 0 & 40 \\
& Reading & 29.30 & 21.09 & 0 & 71.43 \\
& Integrated skills & 39.69 & 32.34 & 0 & 100 \\
\hline
\end{tabular}

$T$-tests were conducted, using a Bonferroni adjustment, to compare the proportions of words from each frequency level (1000, 2000, AWL and Off-list) between the integrated skills textbooks and reading textbooks. It was found that there was a significant difference between the number of AWL words in the two types of books ( $t=3.137, d f=18, p<0.0125)$, with significantly more AWL words appearing in the reading textbooks than the integrated skills textbooks. The proportions of words at the other three frequency levels (1000, 2000 and Off-list) were not found to be significantly different between the two types of textbooks.

\section{Discussion and Conclusion}

Due to the lack of any clear, quantifiable proficiency levels or any guidelines regarding what vocabulary learners at different proficiency levels may be ready to learn, textbook producers are left with the difficult task of trying to determine what level of vocabulary learners at different proficiency levels should be focusing on. However, as shown in Table 1, looking at graded readers may provide a rough guide as to what levels are likely to be appropriate. It is clear that learners beyond the preintermediate or B1 level no longer need to focus on the first 1000 words as an object of direct study, yet 7 out of 10 integrated skills textbooks and 2 out of 10 reading textbooks focused on words from the first 1000 as target words in their textbooks. Furthermore, two of the integrated skills textbooks ('Just right' and 'Aspire'), which claimed to be at the upper-intermediate or B2 level, included $50 \%$ and $60 \%$ of target words from the first 1000 words, respectively. It seems that if learners need to focus 
on these words at the highest frequency level, then they cannot be termed upperintermediate level learners and, therefore, it is highly likely that the vocabulary level of these books is pedagogically inappropriate.

Although the claimed proficiency levels of the reading textbooks and the integrated skills textbooks were almost the same, with two of each type of textbook claiming to be at an intermediate level and the rest claiming to be at higher levels (only one book claimed to be at the advanced level and one book did not state any proficiency level), 6 of the 10 integrated skills textbooks focused predominantly on high-frequency levels $(50 \%$ or more of the target vocabulary from within the first 2000 words). On the other hand, not one of the reading textbooks focused predominantly on high-frequency words $(50 \%$ or more of the target words from within the first 2000 words). It seems clear that reading textbooks are expecting users to know significantly more vocabulary, although they use the same terms to describe the level of the textbook.

It may appear that reading textbooks and integrated skills textbooks have different purposes, and this argument may be used to justify the significantly higher proportion of academic vocabulary in the reading textbooks. However, textbooks may not always be used for the purposes for which they are intended. General ESL schools in English-speaking countries tend to use integrated skills textbooks rather than skill-specific texts. However, they have many learners who aim to be admitted into a formal tertiary education institution. Furthermore, even in pre-sessional EAP programs within universities in English-speaking countries, integrated skills textbooks are often used as the basis of instruction. Although it may be cheap and practical for learners to buy just one textbook and use it to learn all four skills, it seems clear in terms of vocabulary learning that institutions that choose integrated skills textbooks rather than a dedicated reading textbook may be doing a disservice to their students, as reading textbooks provide more recycling of vocabulary through longer texts, more focus on vocabulary and target vocabulary at more suitable frequency levels than integrated skills books.

What was stated by Hulstijn (2007) about the CEFR could also be said of the terms 'beginner', 'elementary', 'intermediate' and 'advanced'. We already have a number of tests which can be given to individual learners to determine their vocabulary knowledge. However, this information has not been linked to proficiency levels. At this point, it seems necessary for vocabulary researchers to find a method of quantifying what learners are expected to know at each level so that textbook producers can clearly communicate the intended audience for their textbooks, enabling teachers and learners to select the material that is most appropriate to their needs.

\section{References}

Cobb, T. (1999). Breadth and depth of vocabulary acquisition with hands-on concordancing. Computer Assisted Language Learning, 12, 345-360.

Cobb, T. (n.d.). Web Vocabprofile. Retrieved from http://www.lextutor.ca/vp/, an adaptation of Heatley, Nation, \& Coxhead's. (2002). Range. 
Council of Europe. (2001). Common European framework of reference for languages: Learning, teaching, assessment. Cambridge: Cambridge University Press.

Coxhead, A. (2000). A new academic word list. TESOL Quarterly, 34, 213-238. doi: $10.2307 / 3587951$

Folse, K. (2004). Vocabulary myths: Applying second language research to classroom teaching. Ann Arbor, MI: The University of Michigan Press.

Heatley, A., Nation, I. S. P., \& Coxhead, A. (2002). RANGE and FREQUENCY programs. Retrieved from http://www.victoria.ac.nz/lals/staff/paul-nation

Hulstijn, J. (2007). The shaky ground beneath the CEFR: Quantitative and qualitative dimensions of language proficiency. Modern Language Journal, 91, 663-667. Retrieved from http://www.jstor.org/stable/4626094

Nation, I. S. P. (2001). Learning vocabulary in another language. Cambridge, UK: Cambridge University Press.

West, M. (1953). A general service list of English words. London, UK: Longman, Green \& Co. 